\title{
CONTRIBUTION TO THE BIOGEOGRAPHY OF ARCTIC-ALPINE FUNGI: FIRST RECORDS IN THE SOUTHERN CARPATHIANS (ROMANIA)
}

\section{A. Ronikier}

Ronikier, A. 2008. Contribution to the biogeography of arctic-alpine fungi: first records in the Southern Carpathians (Romania). - Sommerfeltia 31: 191-211. ISBN 82-7420-045-4. ISSN 0800-6865.

A list of 24 species collected in the alpine zone of the Southern Carpathians is given. Fourteen species are new to Romania and the Southern Carpathians; five have not been previously reported from the Carpathian Mts. A synopsis of the geographical distribution of eleven species representing the arctic-alpine element is included. The seven most interesting species, Inocybe alboperonata, I. microfastigiata, I. nespiakii, I. oreina, Lactarius brunneoviolaceus, L. nanus, and Russula heterochroa, are described and illustrations of their microcharacters are given.

Keywords: Alpine agarics, Basidiomycetes, Romania, Southern Carpathians.

Anna Ronikier, Department of Mycology, Institute of Botany, Polish Academy of Sciences, Lubicz 46, PL-31-512 Kraków, Poland

\section{INTRODUCTION}

Arctic-alpine agarics are known to occur in the arctic areas of Europe, Asia and North America. In Europe, a substantial amount of data has been gathered for the Alps while much less is known about the distribution of this group of fungi in other alpine areas. Very few records are available from the Carpathians, and no mycological investigations have been carried out in the alpine areas of the southern and eastern parts of this mountain range to date. The main objective of this work is to present the first records of fungi collected in the alpine zone of the Southern Carpathians (Romania). Special attention is paid to the arctic-alpine element.

\section{STUDY AREA}

The Carpathians constitute a major mountain system in Europe. Situated in the south-eastern part of the continent, they extend through Slovakia, Poland, Ukraine and Romania (Fig. 1). Approximately $55 \%$ of the range belongs to Romania, covering almost 30\% of its territory (Ronikier 1996a). The Carpathian Mts are divided into three parts: the Western Carpathians (Slovakia and Poland), the Eastern 
Carpathians (Poland, Slovakia, Ukraine and Romania), and the Southern Carpathians (Romania). The latter constitute a mountain chain about $320 \mathrm{~km}$ long running from the east to the west. They reach the Predeal pass $(1033 \mathrm{~m})$ in the vicinity of Braşov in the West and the gorge of the Donau river, called Porțile de Fier in the East (Ronikier 1996b). A characteristic feature of the Southern Carpathians is a high average altitude; $10 \%$ of the area reaches more than $2000 \mathrm{~m}$ a.s.l. Because of intensive pastoral culture developed in the Romanian Carpathians, alpine and subalpine meadows cover extensive areas in the mountain landscape, extending down to relatively low altitudes (Ronikier 1996b), at the expense of subalpine dwarf pine forests and patches of Rhododendron myrtifolium Schott et Kotschy and Juniperus communis L. ssp. alpina (Sm.) Čelak.

The Southern Carpathians are composed of several well differentiated massifs: Munții Făgăraşului, Munții Iezer-Păpuşa, Munții Leaota, Munții Bucegi, Piatra Craiului, Munții Parîng, Munții Căpăținii, Munții Lotru, Munții Cindrel, Munții Latoriței, Munții Sebeşului, Munții Retezat, Munții Țarcu, Munții Godeanu, and some smaller ones. One national park is established in the Southern Carpathians, Parcul Național Retezat, and three other parks are planned; in Munții Bucegi, in Piatra Craiului and in the small massif Cozia situated between Munții Făgăraşului and Munții Lotru (Soran et al. 2000). Several areas are protected as nature reserves.

Six main massifs were studied: Munții Făgăraşului, Munții Iezer-Păpuşa, Munții Bucegi, Munții Lotru, Munții Cindrel and Munții Latoriței (Fig. 1). The vegetation of these massifs is conditioned on the bedrock. Munții Bucegi and Munții Latoriței are built up of limestone-rich rocks. Typical calcareous ectomycorrhizal plant species, such as Salix reticulata L. and Dryas octopetala L., are abundant in the former massif while they are completely absent throughout the latter. The other four massifs are mostly granitic. The Iezer-Păpuşa, Lotru and Cindrel Mts. are dominated by poor, crystalline-bedrock grasslands. Salix herbacea L. and Polygonum viviparum L. occur there as the only mycorrhizal hosts. In Munții Făgăraşului, there are many places richer in nutrients, especially along the edges of the main ridge cliffs and in schistous slopes; Salix reticulata and Dryas octopetala are often encountered.

\section{MATERIAL AND METHODS}

Extensive field work was carried out in the alpine belt of the Southern Carpathians in July and August 2004.

Most collections of fungi were made by Anna Ronikier and Michał Ronikier (AR, MR); some collections were made by Elżbieta Cieślak (EC) or Jakub Cieślak (JC). The entire material is deposited at the Herbarium of the Institute of Botany, Polish Academy of Sciences, Cracow (KRAM).

References to colours follow Kornerup \& Wanscher (1965).

\section{RESULTS}

About 200 collections were made during the field work of which 77 have been examined for this paper. A total of 24 species have been identified, of which 11 are arctic-alpine and 13 species are typical grassland species (Hygrocybe spp.) or ubiquitous species that occur in various habitats and also frequently in the alpine zone. Fourteen species have not previously been reported from Romania 

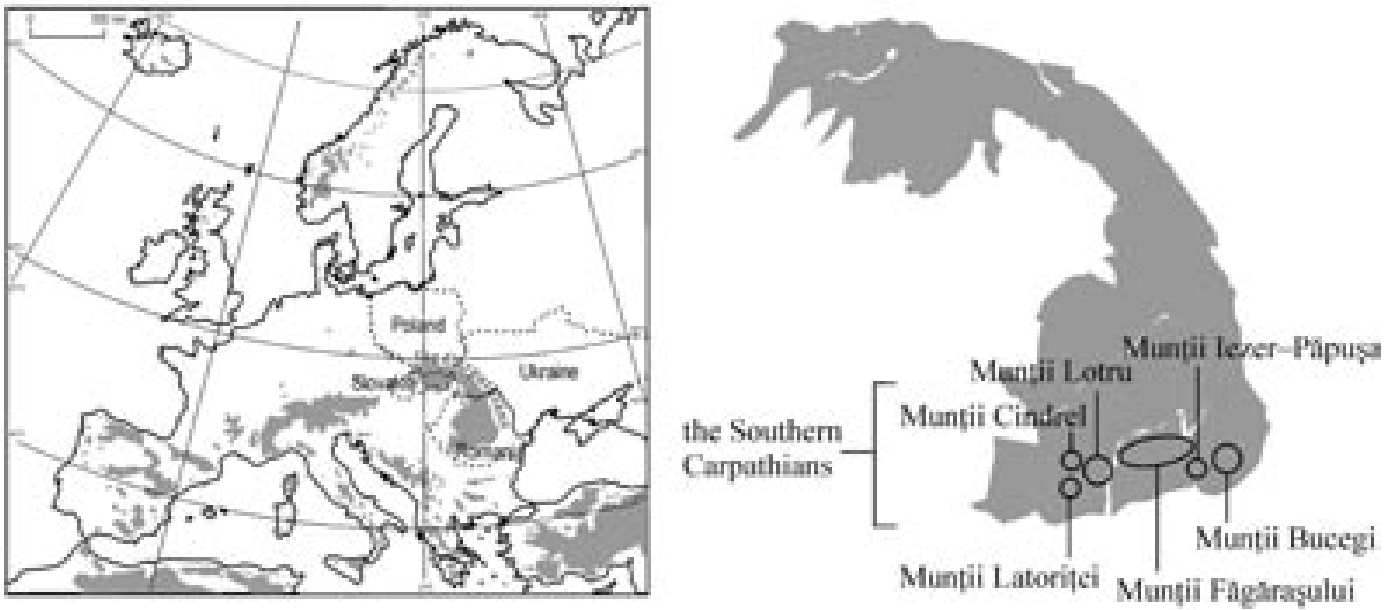

Fig. 1. Location of the Carpathians in Europe (left) and the massifs examined (right).

and from the Southern Carpathians: Amanita nivalis, Hygrocybe turunda, Inocybe alboperonata, I. dulcamara, I. microfastigiata, I. nespiakii, I. oreina, Lactarius brunneoviolaceus, L. nanus, Lichenomphalia alpina, Mycena citrinomarginata, Russula heterochroa, R. nana, R. saliceticola. Five species: Inocybe alboperonata, I. microfastigiata, I. oreina, Lactarius brunneoviolaceus, and Russula heterochroa are new to the Carpathians.

\section{DISCUSSION}

Over 2000 species of Basidiomycetes are known to occur in Romania (Bontea 1985). Results of mycological investigations in the Romanian Carpathians have been reported in numerous publications; those, however, focus mostly on microfungi or forest macrofungi. The body of data on macrofungi recorded in Munții Bucegi is fairly substantial (Kotlaba 1959, Eliade 1961, 1963, 1964, Eliade \& Toma 1977), and some records from Munții Leaota (Toma \& Diaconescu 1971) and Retezat (Pop 1989) are also available. Only three species of macrofungi are, however, encountered in the altitude between 1800 and $2500 \mathrm{~m}$ in Munții Bucegi; listed under the names "Deconica coprophylla (Fr. ex Bull.) Karst, Amanitopsis vaginata (Bull.) Roze and Lactarius rufus (Scop.) Fr.” (Eliade 1963). To the best of my knowledge, no previous published information exist on alpine fungi of the Southern Carpathians. Thus, the present paper provides the first well documented observations of fungi from the alpine zone of the Southern Carpathians. It clearly demonstrates that these mountains host a fungal flora that is fairly rich in species of this ecological group of fungi.

Russula nana was the most common species in alpine areas in the Southern Carpathians. Although found only in two massifs, it was very common, occurring not only with dwarf shrubs (Dryas octopetala and/or Salix spp.) but also in those areas where Polygonum viviparum was the only present potential mycorrhizal partner. The species is also known from the Western Carpathians, where it is one of the most frequent arctic-alpine fungi.

Three species of Lichenomphalia were also encountered in the Southern Carpathians with 
high frequency. Lichenomphalia hudsoniana, which is also very frequent in the Western Carpathians (Lisicka 1999, Olech 2004), was the most common of these species. L. alpina is known only from few localities in the Western Carpathians.

Some rare species of fungi are reported for the first time from the Southern Carpathians. Russula heterochroa is a very rare species, reported only from the French Alps and Swedish Lapland, while Inocybe nespiakii is known from the Alps and the Western Carpathians. Inocybe alboperonata had previously been reported from alpine zones of the Alps and the Pyrenees. These three species were found in the Munții Bucegi or Munții Latoriței massifs. These two calcareous regions of the Southern Carpathians as well as the others not yet investigated within the present project seem to be the most promising among Carpathian areas with respect to fungal species richness, due to presence of many rare, calciphilous species.

The data collected are insufficient to acquire a general picture of the distribution of fungi in both the Southern Carpathians and the entire Carpathian system, but some indications emerge. As the alpine (and also subalpine) meadows cover extensive areas in the Southern Carpathians, high richness of fungi associated with grassland vegetation can be expected in the area. Furthermore, high diversity of bedrock types, giving rise to variation in edaphic conditions, results in the occurrence both of species requiring nutrient-rich soils and species that prefer oligotrophic sites. This environmental and vegetational variability suggests that this region has a potential for high fungal species richness.

\section{COMMENTED LIST OF SPECIES}

\section{Amanita nivalis Grev.}

Observations. Four carpophores were found growing in one place, on a large stone covered with a soil layer and Salix retusa. One carpophore (KRAM F-54854) had a greyish cap without veil remnants and a pure white volva while three others (KRAM F-54853) had a paler beige cap covered with numerous small volval warts with an ochraceous tinge and a pale brownish spotted volva. All specimens had white pruinose-floccose stipes without any girdles. Macroscopic and microscopic features of the collected specimens are consistent with the detailed description provided by Knudsen \& Borgen (1987).

Notes on distribution. Amanita nivalis is known from arctic and subarctic areas of Finland, Greenland, Norway, Sweden, Russia (Polar Urals), from the Faroe Islands, Iceland and Scotland, alpine zones of the Norwegian mountains as well as the Swiss, French, Italian, Austrian and German Alps, the Pyrenees and the Western Carpathians (Favre 1955, Lange 1955, Gulden \& Lange 1971, Kühner 1972, Bas 1977, Watling 1977, Bresinsky \& Schmid-Heckel 1983, Trimbach 1983, Watling 1983, Bon 1985a, Gulden et al. 1985, Schmid-Heckel 1985, Gerhold 1986, Kühner \& Lamoure 1986, Bon 1987a, 1987b, Bon \& Cheype 1987, Knudsen \& Borgen 1987, Watling 1987, Tondl 1989a, Bon 1990, Elborne \& Knudsen 1990, Bon 1991, Hansen \& Knudsen 1992, Knudsen \& Mukhin 1998, Vesterholt 1998, Vila et al. 1998, Škubla 1999, Campo \& Bizio 2000, Knudsen \& Ronikier 2003, Niezdoiminogo 2003, G. Gulden pers. comm.). The species is new to Romania.

Amanita nivalis had not previously been reported from Romania; however, "Amanitopsis vaginata (Bull.) Roze" is listed among fungi found at the altitude 1800-2500 m in Munții Bucegi (Eliade 1963). This record may belong to A. nivalis.

Specimen examined. Munții Făgăraşului, upper part of the Valea Podragului valley (towards the Şaua Podragului pass), on a large stone covered with Salix retusa, N 45³6'17', E 2441'18”, alt. 2270 m, 05-08-2004, leg. AR, MR, KRAM F-54853, 54854 . 


\section{Entoloma conferendum (Britzelm.) Noordel.}

Notes on distribution. Entoloma conferendum occurs in various habitats, and although it is not an arctic-alpine fungus, it occurs commonly in the alpine zone of European mountains (e.g. Gulden \& Lange 1971, Kühner \& Lamoure 1985, Horak 1993, Vila et al. 1998). It is also very common in the Western Carpathians (Knudsen \& Ronikier 2003).

Specimens examined. Munții Făgăraşului, upper part of the Valea Caprei valley, subalpine meadow (pasture), among mosses, N 45³5'23”, E 2438'49”, alt. 1700 m, 03-07-2004, leg. AR, MR, KRAM F-54900; E ridge of the Țarâta peak, alpine meadow, among Polygonum viviparum and Dryas octopetala, N 4536'20', E 2441'42”, alt. 2400 m, 05-08-2004, leg. AR, MR, KRAM F-54897; S-E slope of the Vf. Corabia peak, alpine meadow, N 45³6'13”, E 2443'01'”, alt. 2300 m, 05-08-2004, leg. AR, MR, KRAM F-54899; E slopes the Viştea Mare peak, alpine meadow, among grass, N 45³6’11’”, E $24^{\circ} 44^{\prime} 10^{\prime \prime}$, alt. $2480 \mathrm{~m}, 07-08-2004$, leg. AR, MR, KRAM F-54898; upper E part of the Valea Rea valley, alpine meadow, snow-bed, N 45³6'27’, E 2445'52”, alt. 2160 m, 07-08-2004, leg. AR, MR, KRAM F-54896.

\section{Gymnopus dryophilus (Bull.: Fr.) Murrill}

Notes on distribution. Gymnopus dryophilus is one of the most common and widely distributed Gymnopus species. It is also quite common in arctic-alpine habitats (e.g. Gulden \& Lange 1971, Kühner \& Lamoure 1985, Schmid-Heckel 1985).

Specimens examined. Munții Iezer-Păpuşa, vicinity of lake Lacul Iezeru, alpine meadow, N 45²7'38', E 245 ' $40^{\prime \prime}$, alt. 2140 m, 30-07-2004, leg. AR, MR, KRAM F-54913; N 45²7’35”, E 2457’41’”, alt. 2400 m, 01-08-2004, leg. AR, MR, KRAM F-54915; the Curmătură Oticului pass, subalpine/alpine meadow, among Rhododendron myrtifolium, N 4529'42'”, E 2456'17', alt. 1850 m, 31-07-2004, leg. AR, MR, KRAM F-54914;

\section{Hygrocybe chlorophana (Fr.: Fr.) Wünsche}

Notes on distribution. The fungus is not associated with the alpine zone, but it is known from alpine habitats (e.g. Kühner 1977, Jamoni 1998-99). The species is typical of grassland vegetation (Boertmann 2000).

Specimen examined. Munții Latoriței, N-W slopes of the Vf. Fratoșteanu Mare peak, alpine pasture on calcareous bedrock, among grass, N 45²4’26”, E 2347’37”, alt. 1960 m, 16-08-2004, leg. AR, MR, KRAM F-54909.

\section{Hygrocybe conica (Schaeff.: Fr.) P.Kumm.}

Notes on distribution. Hygrocybe conica is a widely distributed species occurring in many different habitats. Many reports are available from arctic-subarctic and alpine-subalpine regions of the northern and southern hemispheres (Boertmann 2000). The species is also common in alpine and subalpine meadows of the Western Carpathians (A. Ronikier, unpublished data).

Specimens examined. Munții Bucegi, main plateau, slopes between the Cabana Babele hostel and Muntele Caraiman,

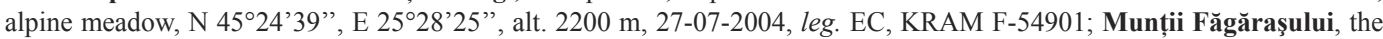
Şaua Caprei pass, alpine meadow, among Thymus sp., N 45³6’10”, E 24³7’34”, alt. 2315 m, 08-08-2004, leg. AR, MR, KRAM F-54902; the Valea Sâmbăta valley, Piatra Caprei, subalpine meadow, among stones (calcareous), N 45³7'48'”, E 2448'16”, alt. 1750 m, 10-08-2004, leg. AR, MR, KRAM F-54903; Munții Latoriței, the ridge of the Vf. Fratoşteanu Mare peak, alpine meadow, among grass, N 45²4'38', E 2347'57', alt. 1980 m, 16-08-2004, leg. AR, MR, KRAM F-54904; the slope between the Curmătură Vidruței pass and the Vf. Fratoşteanu Mare peak, subalpine/alpine meadow, among grass, N 4524'45”, E 2347’45”, alt. 1870 m, 16-08-2004, leg. AR, MR, KRAM F-54905.

\section{Hygrocybe pratensis (Pers.: Fr.) Murrill}

Notes on distribution. Hygrocybe pratensis is a common species, occurring on almost all continents (Boertmann 2000). It is also frequent in the arctic-alpine regions (e.g. Favre 1955, Kühner \& Lamoure 1986, Jamoni 1998-99, Vila et al. 2001, Borgen \& Arnolds 2004).

Specimens examined. Munții Făgăraşului, upper part of the Valea Caprei valley, alpine/subalpine meadow (pasture), N 45³5'23”, E 24³8'49”, alt. 1700 m, 12-08-2004, leg. AR, MR, KRAM F- 54865; Munții Lotru, N slope of the

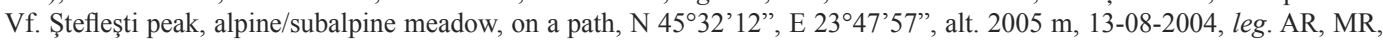




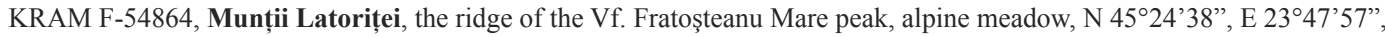
alt. 1980 m, 16-08-2004, leg. AR, MR, KRAM F-54866.

Hygrocybe psittacina (Schaeff.: Fr.) P.Kumm.

Notes on distribution. Like the three species mentioned above (Hygrocybe chlorophana, H. conica and $H$. pratensis), Hygrocybe psittacina is a widespread species which also occurs in subarctic and subalpine-alpine meadows (Boertmann 2000).

Specimen examined. Munții Latoriței, N-W slopes of the Vf. Fratoșteanu Mare peak, alpine pasture on calcareous bedrock, among grass, N 45²4'26”, E 2347’37”, alt. 1960 m, 16-08-2004, leg. AR, MR, KRAM F-54911.

Hygrocybe turunda (Fr.: Fr.) P.Karst.

Observations. The collection from the Southern Carpathians is characterized by orange to orangereddish $(6 \mathrm{~A} 8,7 \mathrm{~A} 8,8 \mathrm{~A} 8)$ paling to yellow-buff $(4 \mathrm{~A} 5)$ pilei covered with dark violet-brown, almost black (11F3-4, 12F3) squamules and by pale yellow (2A5), decurrent lamellae.

Taxonomic notes. The macro- and microcharacteristics of the specimens are consistent with the descriptions given by Boertmann (2000) and Borgen \& Arnolds (2004).

Notes on distribution. The fungus has a boreal-montane, low alpine to (sub-) arctic distribution (Borgen \& Arnolds 2004). The species is new to Romania.

Specimen examined. Munții Latoriței, $\mathrm{N}$ slopes of the Vf. Fratoșteanu Mare peak, alpine meadow, among mosses, N 4524'38', E 234'ㄱ'”, alt. 1980 m, 16-08-2004, leg. AR, MR, KRAM F-54910.

\section{Inocybe alboperonata Kühner}

Fig. 2.

Description. Cap 1-2 cm in diameter, campanulate with prominent umbo and decurved margin, greyish brown, clay-buff, dark greyish buff $(5 \mathrm{C} 3-4,5 \mathrm{D} 3-4)$, surface covered with white veil giving fibrillose-squamulose appearance, darker brown under veil. Lamellae greyish yellow, beige (4B3, $4 \mathrm{C} 3$ ), moderately distant, adnate, up to $3 \mathrm{~mm}$ broad, edge whitish ciliate. Stipe $2-5 \times 0.4 \times 0.6 \mathrm{~cm}$, cylindrical, white when young because of a thick layer of white veil, isabella (5D6) under veil, not pruinose or only at extreme apex. Flesh whitish, smell spermatic, taste mild.

Spores amygdaliform with conical apex, 9.5-12 × 5.5-6 $\mu \mathrm{m}$. Basidia 31-35 $\times 8-11 \mu \mathrm{m}$, with 4 sterigmata. Cheilocystidia cylindrical to fusiform, $60-104 \times 11-18 \mu \mathrm{m}$, walls $1-1.5(2.5) \mu \mathrm{m}$. Pleurocystidia similar, 50-110 $\times 11-25 \mu \mathrm{m}$, scattered. Caulocystidia not well developed, rare, present only in extreme apex of the stipe, cylindrical, fusiform or lageniform, 70-140 × 11-26 $\mu \mathrm{m}$.

Taxonomic notes. A discussion of closely related taxa is provided by Esteve-Raventós \& Vila (1998).

Ecological notes. Inocybe alboperonata is considered to be a calciphilous species associated with Salix and Dryas (Esteve-Raventós \& Vila 1998). The Carpathian record accord with the anticipated ecological preferences of the species: it was also found on limestone, with Polygonum viviparum as the only potential mycorrhizal host.

Notes on distribution. Inocybe alboperonata has been reported from the Alps (Kühner 1988) and the Pyrenees (Esteve-Raventós \& Vila 1998). The species is new to the Carpathians and Romania.

Specimen examined. Munții Latoriței, the Vf. Mogoșu peak, alpine meadow with Polygonum viviparum, N 45 $24^{\prime} 26^{\prime \prime}$, E 234'37’, alt. 1960 m, 16-08-2004, leg. AR, MR, KRAM F-55178.

Inocybe dulcamara (Alb.\& Schwein. ex Pers.) P.Kumm.

Notes on distribution. Inocybe dulcamara is a widespread and greatly variable species, very often 


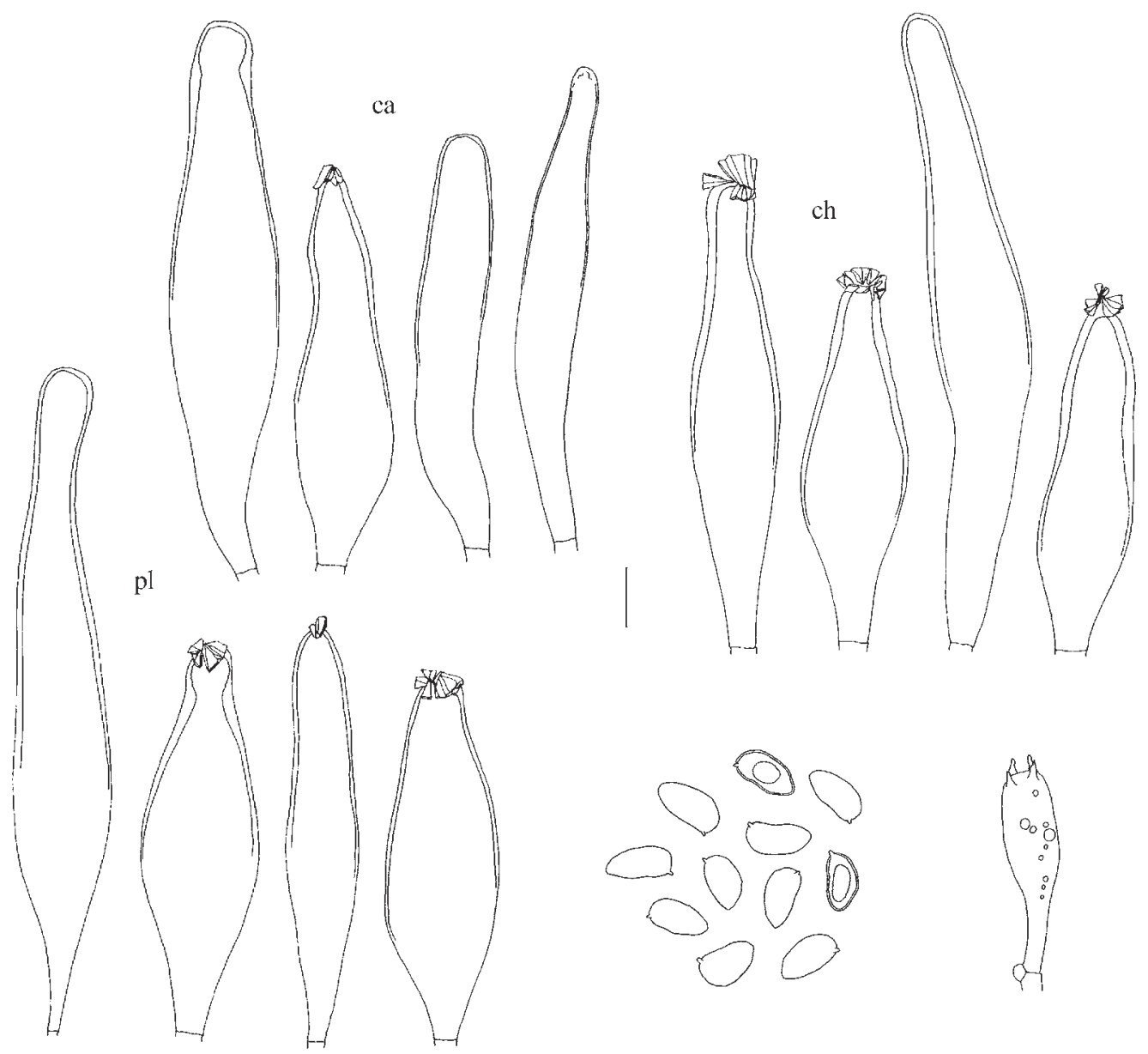

Fig. 2. Inocybe alboperonata Kühner, coll. KRAM F-55178: ch - cheilocystidia, pl - pleurocystidia, ca - caulocystidia; scale bar $=10 \mu \mathrm{m}$.

reported from arctic-alpine habitats (e.g. Favre 1955, Vila et al. 2001, Niezdoiminogo 2003). The species is new to Romania.

Specimen examined. Munții Bucegi, Muntele Caraiman, calcareous (?) rocks near the marked trail to the Vf. Caraiman peak, alpine meadow, with Dryas octopetala and Salix reticulata, N 45²4'51', E 25²9’34', alt. 2300 m, 26-07-2004, leg. AR, MR, KRAM F-55174.

\section{Inocybe lacera (Fr.) P.Kumm.}

Notes on distribution. Inocybe lacera is a greatly variable species occurring in lowlands and quite common in alpine habitats (e.g. Favre 1955, Gulden \& Lange 1971).

Specimens examined. Munții Lotru, the Vf. Cristești peak, alpine meadow with Salix herbacea, N 45³1'37’, E 2347'24”, alt. 2182 m, 13-08-2004, leg. AR, MR, KRAM F-55176; the Vf. Ştefleşti peak, edge of the postglacial kettle, alpine meadow with Salix herbacea, N 45³1'55', E 2348'27”, alt. 2220 m, 13-08-2004, leg. AR, MR, KRAM F-55177. 


\section{Inocybe microfastigiata Kühner}

Fig. 3.

Description. Cap 1.5-2 cm in diameter, conical, straw yellowish brown, honey-coloured (4B4-6) with darker, yellowish brown centre (5D7), surface rimose, margin decurved in young specimens and white ciliate because of veil remnants. Lamellae pale greyish-yellow (3B4), moderately crowded, adnate, broad. Stipe $2-2.5 \times 0.3 \times 0.4 \mathrm{~cm}$, cylindrical or subbulbose, white, longitudinally fibrillose, apex pruinose. Flesh white, pale ochraceous at base, smell herb-like, taste none.

Spores ellipsoid, subphaseoliform 11-12 × 6-7 $\mu \mathrm{m}$. Basidia 35-37 × 10-11 $\mu \mathrm{m}$, with 4 sterigmata. Pleurocystidia absent. Cheilocystidia cylindrical, narrowly clavate, thin-walled, some septate, $35-55 \times 9-12 \mu \mathrm{m}$. Caulocystidia present only at stipe apex, cylindrical, thin walled, very long, up to $>100 \mu \mathrm{m}, 7-12 \mu \mathrm{m}$ in diameter, septate.

Notes on distribution. Inocybe microfastigiata is known from the Swiss, French and Italian Alps (Kühner \& Lamoure 1986, Bon 1992, Jamoni \& Bon 1995). However, as the taxonomy of the Inocybe fastigiata group is in need of revision, the actual geographical distribution of I. microfastigiata is not known. The species is new to the Carpathians and Romania.

Specimen examined. Munții Bucegi, Muntele Caraiman, calcareous (?) rocks near the marked trail to the Vf. Caraiman peak, alpine meadow with Dryas octopetala and Salix reticulata, N 45'24'51', E 25'29'34", alt. 2400 m, 26-07-2004, leg. AR, MR, KRAM F-55179.

\section{Inocybe nespiakii Bon}

Fig. 4.

Description. Cap 1-2 cm in diameter, convex with a decurved margin, then plane with slightly depressed centre, yellowish brown, brownish olive (5D6-7, 5E6-7), surface tomentose, fibrillose or slightly squamulose. Lamellae yellowish buff (4C6, 4C7), then brownish (4F8, 5F8), moderately crowded, adnate, broad. Stipe 1-1.5 $\times 0.3 \times 0.5 \mathrm{~cm}$, cylindrical, honey-coloured (4B4, 4B5), without distinct remnants of veil, longitudally fibrillose, hollow. Flesh whitish chrome (3A2), without smell and taste. Veil inconspicuous.

Spores ellipsoid-cylindrical, 10-14(15) $\times 5-6 \mu \mathrm{m}$. Basidia 35-42 $\times 10-11 \mu \mathrm{m}$, with 4 sterigmata. Cheilocystidia cylindrical to broadly clavate or almost spherical, 25-38 $\times 10-20(36) \mu \mathrm{m}$.

Taxonomic notes. The name I. nespiakii was created by Bon (1996) as a replacement for the invalid name I. favrei described by Nespiak (1990). I. nespiakii is considered to be an alpine species (Bon 1997). Although Nespiak described the species on the basis of Favre's alpine collection of $I$. dulcamara f. aff. malenconii (Favre 1955), he selected a type collection from the subalpine spruce forest of the Tatra Mts. (Western Carpathians). I. nespiakii is very similar to I. malenconii Heim var. megalospora Stangl \& Bresinsky. According to the original description (Nespiak 1990), the former species is characterized by lack of a distinct cortina (stipe surface is covered by fibrils which do not form any trace of a ring), while the latter taxon has a very well developed veil (Stangl 1989). In the description of I. nespiakii provided by Bon (1997), the stipe of the species is "fibriloso-laineux" or has a thick cortina. The typical I. malenconii has a distinct but fugacious cortina (Heim 1931). As the presence or absence of cortina seems to be a variable feature, it cannot be excluded that $I$. nespiakii is conspecific with I. malenconii var. megalospora and I. malenconii. Bizio (1997) reports I. maleconii from the alpine zone. He also points out the differences between I. malenconii and I. nespiakii, and notices that their similarity makes the distinction between the two species very difficult.

Notes on distribution. Inocybe nespiakii is known from alpine habitats of the Swiss and French Alps (Favre 1955, Kühner \& Lamoure 1986, Bon 1991). I. malenconii reported from the alpine zone of the Italian Alps (Bizio 1997) may be conspecific with the Carpathian specimens examined. The species is new to Romania.

Specimen examined. Munții Bucegi, Muntele Caraiman, calcareous (?) rocks near the marked trail to the Vf. 

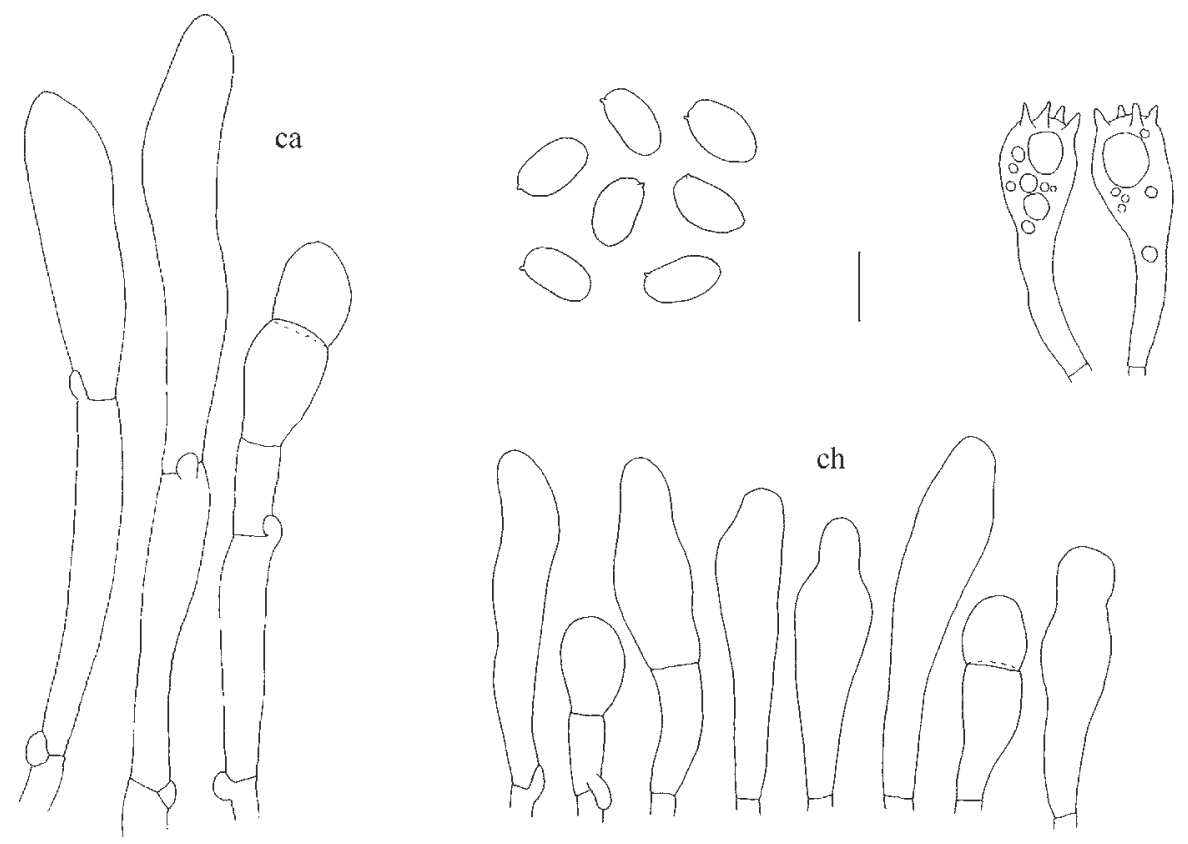

Fig. 3. Inocybe microfastigiata Kühner, coll. KRAM F-55179: ch - cheilocystidia, ca - caulocystidia; scale bar $=10 \mu \mathrm{m}$.
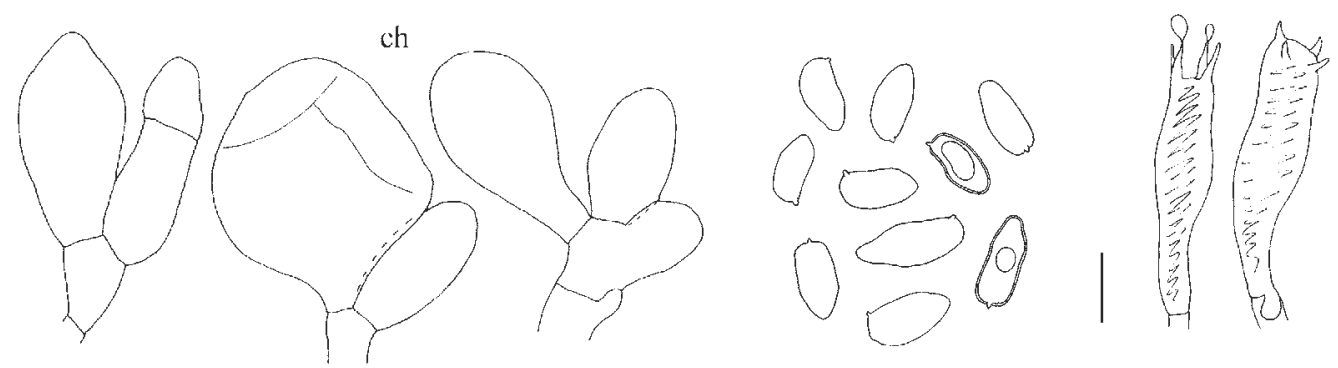

Fig. 4. Inocybe nespiakii Bon, coll. KRAM F-55175: ch - cheilocystidia; scale bar $=10 \mu \mathrm{m}$.

Caraiman peak, alpine meadow, with Dryas octopetala, N 45²4’51’, E 25²9’34”, alt. 2400 m, 26-07-2004, leg. AR, MR, KRAM F-55175.

\section{Inocybe oreina J.Favre}

Fig. 5.

Description. Cap 1.5-2 cm in diameter, conico-campanulate, yellowish brown (5D7, 5E7-8), surface fibrillose arachnoid. Lamellae yellowish beige (4C5, 4D5), moderately crowded, adnate, broad, edge slightly ciliate, paler or brownish. Stipe $2.5-3 \times 0.4 \times 0.5 \mathrm{~cm}$, beige, honey-coloured (4B4), white pruinose over entire length, base bulbose, bulb marginate. Flesh yellowish grey in cap 
(3B4), pale cream in stipe (3A3), without smell and taste. Veil not observed.

Spores bluntly 6-8-angled, 11-14(15) $\times 8-10 \mu \mathrm{m}$. Basidia 41-50 $\times 12-13 \mu \mathrm{m}$, with 4 sterigmata. Cheilocystidia cylindrical to narrowly lageniform-fusiform 70-100 $\times 12-22 \mu \mathrm{m}$, thick walled, walls 1.5-3(4) $\mu \mathrm{m}$. Pleurocystidia similar 65-105 × 14-20 $\mu \mathrm{m}$. Caulocystidia cylindrical 38-140 $\times 10-15 \mu \mathrm{m}$, mostly thin-walled (wall $0.5-1.5 \mu \mathrm{m}$ ), very abundant in upper part of the stipe, less frequent in its lower part.

Taxonomic notes. The shape of spores, intermediate between elliptic (smooth) and nodulose, is the most characteristic feature of the species. Another alpine species, I. concinnula, described by Favre (1955), also has such characteristically angled spores.

Notes on distribution. Inocybe oreina is a rare alpine species, known from the French, Swiss, Italian and German Alps and the alpine zone of the Norwegian mountains (Favre 1955, Bresinsky \& Schmid-Heckel 1982, Bon 1985a, Schmid-Heckel 1985, Kühner \& Lamoure 1986, Horak 1987, Kühner 1988, Bon 1991, 1992, Bizio 1995, G. Gulden, pers. comm.). The locality in Munţii Făgăraşului is the first one in the Carpathians. The species is new to Romania.

Specimen examined. Munții Făgăraşului, N slopes of the Şaua Podragului pass, alpine meadow with Salix retusa,

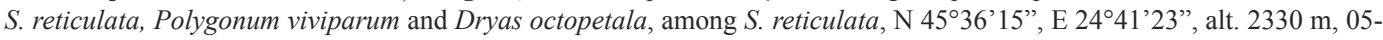
08-2004, leg. AR, MR, KRAM F-55180.

\section{Lactarius brunneoviolaceus M.P.Christ. (=L. robertianus Bon)}

Fig. 6.

Description. Cap 1-3 cm in diameter, convex with a decurved margin, brown vinaceous, vinaceous grey $(8 \mathrm{E} 5,8 \mathrm{~F} 5,8 \mathrm{D} 3,8 \mathrm{E} 3)$, more or less uniformly coloured with withish margin (especially when young), azonate, surface viscid. Lamellae first whitish cream (3A3) then cream (4A3), moderately crowded, adnate or slightly decurrent, narrow, staining violet when bruised. Stipe 1-1.5 $\times 0.5 \times 0.7 \mathrm{~cm}$, cylindrical, white to cream, staining violet when bruised. Flesh white, turning violet when cut, smell characteristic, reminiscent of Lactarius quietus or cedar-oil, taste the same as smell, mild. Milk scarce, white turning violet.

Spores broadly ellipsoid, $10-11 \times 7.5-8.5 \mu \mathrm{m}$, ornamentation low, in the form of ridges and lines forming incomplete reticulum. Basidia $45-53 \times 11-12 \mu \mathrm{m}$, with 4 sterigmata. Pleurocystidia 75-84 $\times 7-10 \mu \mathrm{m}$, narrowly fusiform often with mucronate apex, scattered. Cheilocystidia similar, fusiform to narrowly fusiform, $50-80 \times 7-8 \mu \mathrm{m}$. Pileipellis an ixotrichoderm.

Notes on distribution. Lactarius brunneoviolaceus is a typical arctic-alpine species. It is known from Swedish Lapland and Russian arctic, the Polar Urals, the Faroe Islands, the Norwegian mountains, the Swiss, French, Italian and German Alps, and the Pyrenees (Kühner 1975a, Bon 1985a, 1985b, 1990, 1991, Senn-Irlet 1993, Knudsen \& Mukhin 1998, Vesterholt 1998, Vila et al. 1998, Basso 1999, Bresinsky et al. 2000, G. Gulden, pers. comm.). This species is new to the Carpathians and Romania.

Specimens examined. Munții Făgăraşului, the Țarâta peak, alpine meadow with Salix retusa, S. reticulata, Polygonum viviparum and Dryas octopetala, N 45'36'20”, E 2441'42”, alt. 2440 m, 05-08-2004, leg. AR, MR, KRAM F-55108; the Ucea Mare peak, alpine meadow with Dryas octopetala, N 4536'24”, E 2443'16”, alt. 2400 m, 07-08-2004, leg. AR, MR, KRAM F-55109; the Arpaşu Mare peak, alpine meadow with Dryas octopetala, N $45^{\circ} 35^{\prime} 48^{\prime \prime}$, E $24^{\circ} 40^{\prime} 49^{\prime \prime}$, alt. 2460 m, 12-08-2004, leg. AR, MR, KRAM F-55110.

\section{Lactarius nanus J.Favre}

Fig. 7.

Description. Cap 1-2 $\mathrm{cm}$ in diameter, convex with a decurved margin and very small umbo, dark fawn, clay-buff, fuscous, $(5 \mathrm{C} 4,6 \mathrm{E} 3-4,6 \mathrm{~F} 3-4,7 \mathrm{E} 3-4,7 \mathrm{~F} 3-4)$, more or less uniformly coloured, azonate, surface slightly viscid. Lamellae first whitish cream, pinkish buff (5A4-5, 5B4-5), moderately crowded, adnate, forked at the stem, narrow. Flesh cream to pinkish, taste mild, smell 

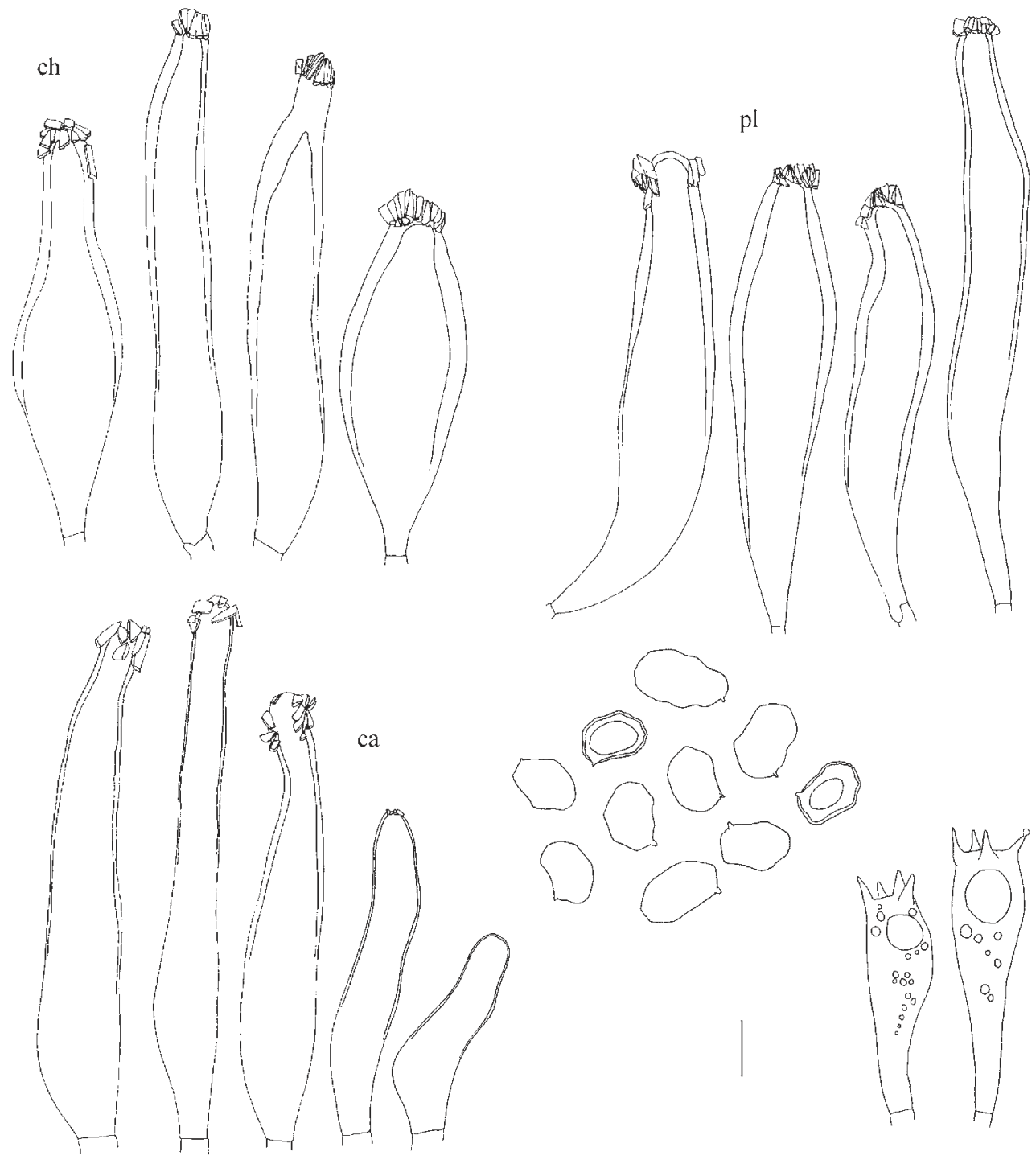

Fig. 5. Inocybe oreina J. Favre, coll. KRAM F-55180: ch - cheilocystidia, pl - pleurocystidia, ca - caulocystidia; scale bar $=10 \mu \mathrm{m}$.

none. Milk very scarce, watery white.

Spores broadly ellipsoid, 7.5-8 $\times 6-6.5 \mu \mathrm{m}$, ornamentation low, in the form of ridges and lines forming incomplete reticulum. Basidia 35-42 $\times 11-12 \mu \mathrm{m}$, with 4 sterigmata. Pleurocystidia 43-65 $\times 7-8 \mu \mathrm{m}$, cylindrical with obtuse apex, rarely mucronate, scattered. Cheilocystidia similar, mostly with obtuse apex, 40-50 × 7-9 $\mu \mathrm{m}$. Pileipellis an ixocutis $30-40 \mu \mathrm{m}$ thick.

Notes on distribution. Lactarius nanus is one of the most common arctic-alpine species of the genus, more frequently encountered in the alpine zone than in the Arctic. It is known from northern Canada, Norway, Sweden, Finland, Russia, Svalbard, Greenland, Iceland, the Faroe Islands, Ireland, 

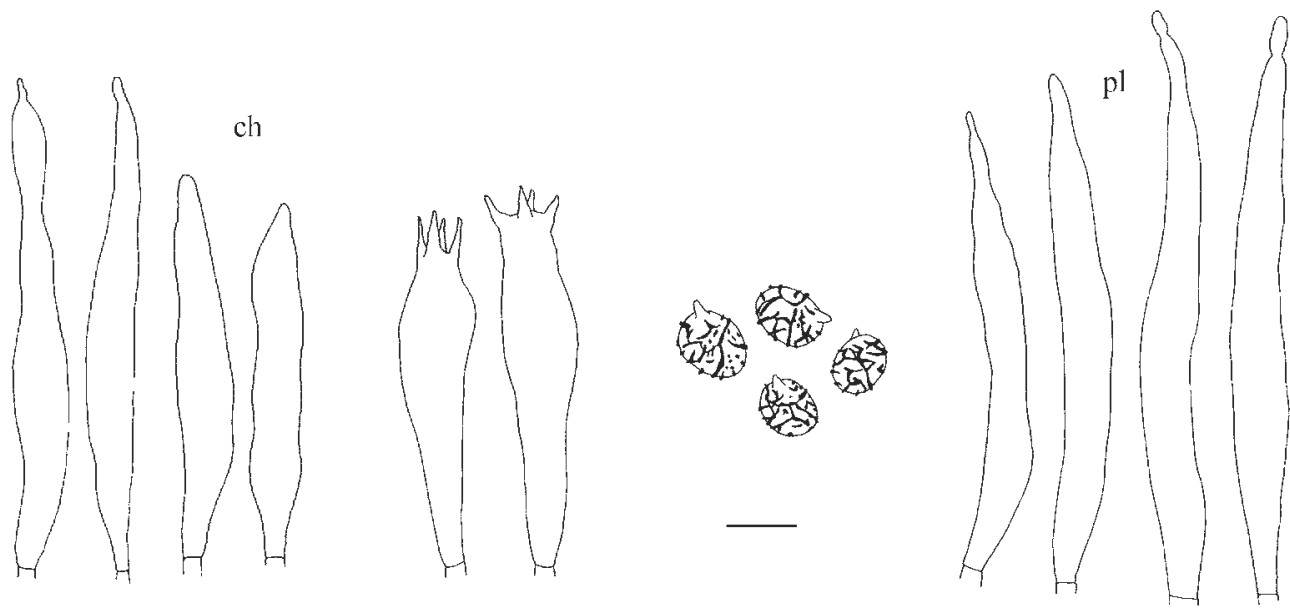

Fig. 6. Lactarius brunneoviolaceus M. P. Christ., coll. KRAM F-55108: ch - cheilocystidia, pl - pleurocystidia; scale bar $=10 \mu \mathrm{m}$.
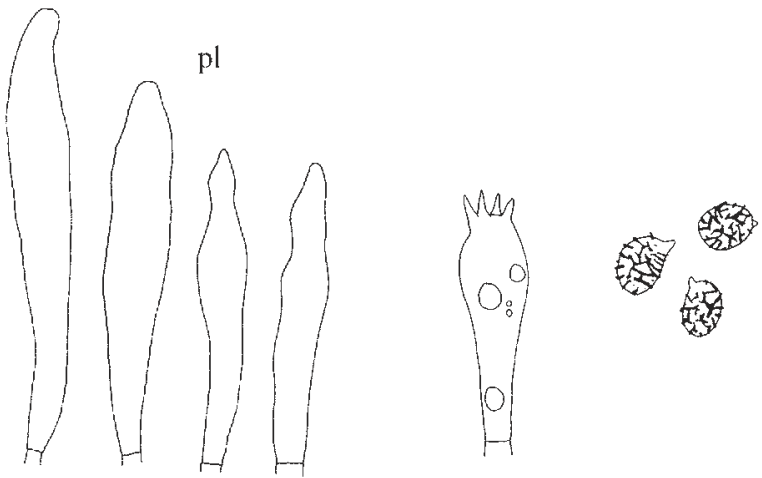

ch

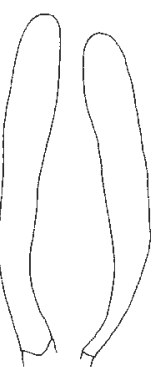

Fig. 7. Lactarius nanus J. Favre, coll. KRAM F-55142: ch - cheilocystidia, pl - pleurocystidia; scale bar $=10 \mu \mathrm{m}$.

from the alpine zone of the Norwegian and Swedish mountains, the Austrian, Swiss, French, Italian and German Alps, the Pyrenees and North American mountains (Favre 1955, Horak 1960, Gulden \& Lange 1971, Kühner 1975a, Knudsen \& Borgen 1982, Lamoure 1982, Lamoure et al. 1982, Bon 1985a, Gulden et al. 1985, Schmid-Heckel 1985, Kühner \& Lamoure 1986, Bon \& Cheype 1987, Moser \& McNight 1987, Senn-Irlet 1987, Bon 1990, 1991, Hansen \& Knudsen 1992, Ohenoja \& Ohenoja 1993, Senn-Irlet 1993, Bon \& Ballarà 1996, Peintner 1998, Vesterholt 1998, Basso 1999, Bresinsky et al. 2000, Vila et al. 2001, Niezdoiminogo 2003, G. Gulden pers. comm.). The species has also been found several times in the alpine zone of the Western Carpathians and has been reported from Ukraine (Fellner \& Landa 1991, 1993, Skirgiełło 1998, Škubla 1999, Antonín \& Škubla 2000). The species is new to Romania.

Specimen examined. Munții Latoriței, the ridge of the Vf. Fratoşteanu Mare peak, alpine meadow with Polygonum viviparum, N 4524'38', E 2347'57’, alt. 1980 m, 16-08-2004, leg. AR, MR, KRAM F-55142. 


\section{Lichenomphalia alpina (Britzelm.) Redhead, Lutzoni, Moncalvo \& Vilgalys}

Notes on distribution. Lichenomphalia alpina is a typical arctic-alpine species widely distributed but not as common as L. hudsoniana. It is known from arctic-subarctic areas of Sweden, Norway, Finland, Russia, Canada, Alaska, from Svalbard, Greenland, Iceland, the Faroe Islands, Scotland, alpine zones of the Norwegian mountains and the French and Swiss Alps (Favre 1955, Lange 1955, Miller 1968, Bigelow 1970, Gulden \& Lange 1971, Watling 1977, Lamoure et al. 1982, Watling 1983, 1987, Hansen \& Knudsen 1992, Lamoure 1993, Vesterholt 1998, Niezdoiminogo 2003, G. Gulden, pers. comm.). Lichenomphalia alpina has also been reported from the Western Carpathians (Bujakiewicz 1993, Flakus \& Bielczyk 2006) but it seems to be very rare there. The species is also known from the Andes in South America and from lowland sites (Gulden et al. 1985). The species is new to Romania.

Specimens examined. Munții Făgăraşului, the Țarâta peak, alpine meadow, among rocks, N 45³6'20", E 2441' $42^{\prime \prime}$, alt. 2440 m, 05-08-2004, leg. AR, MR, KRAM F-54880; the Moldoveanu peak, alpine meadow, N 45³6'11'", E 2444'10”,' alt. 2540 m, 07-08-2004, leg. AR, MR, KRAM F-54885; the Arpaşu Mic peak, alpine meadow, N 4535'46”, E 2439’34”, alt. 2455 m, 12-08-2004, leg. AR, MR, KRAM F-54879; Munții Iezer-Păpuşa, slopes of the Iezeru Mare peak towards lake Lacul Iezeru, alpine meadow, among rocks, N 45²7'24', E 2457'43”, alt. 2170 m, 30-07-2004, leg. AR, MR, KRAM

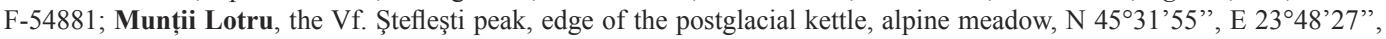
alt. 2220 m, 13-08-2004, leg. AR, MR, KRAM F-54882; Munții Cindrel, the Vf. Cindrelu Mare peak, Căldarea Iezeru Mic, alpine meadow, N 45³4'43”, E 2348'07', alt. 2200 m, 14-08-2004, leg. AR, MR, KRAM F-54883.

Lichenomphalia hudsoniana (H.S.Jenn.) Redhead, Lutzoni, Moncalvo \& Vilgalys

Notes on distribution. Lichenomphalia hudsoniana is one of the most common arctic-alpine species occurring mainly in the alpine zone and arctic areas, but descending to subalpine and subarctic belts. It has also been reported from lowland sites in Denmark (Gulden et al. 1985). The species is known from arctic and subarctic areas of northern Norway, Sweden and Finland, from Svalbard, Greenland, the Faroe Islands, Scotland, Alaska, northern Canada, Russia, North American mountains, Norwegian mountains, the Swiss Alps and from the alpine zone of South American mountains (Favre 1955, Lange \& Skifte 1967, Bigelow 1970, Gulden \& Lange 1971, Watling 1977, Lamoure et al. 1982, Miller 1982, Watling 1983, Gulden et al. 1985, Schmid-Heckel 1985, Redhead \& Kyuper 1987, Watling 1987, Hansen \& Knudsen 1992, Lamoure 1993, Knudsen \& Mukhin 1998, Vesterholt 1998, Niezdoiminogo 2003, G. Gulden, pers. comm.). L. hudsoniana is also very common in the Western Carpathians (Adamčik 1998b, Tondl 1989b, Lisicka 1999, Olech 2004).

The species has been reported by lichenologists from the Southern Carpathians as Coriscium viride Wain. (Moruzi et al. 1967).

Specimens examined. Munții Făgăraşului, the Țarâta peak, alpine meadow with Salix retusa, S. reticulata, Polygonum viviparum and Dryas octopetala, N 45'36'20", E 2441'42”, alt. 2440 m, 05-08-2004, leg. AR, MR, KRAM F-54867; the Moldoveanu peak, alpine meadow, N 45³6'11', E 2444'10”, alt. 2540 m, 07-08-2004, leg. AR, MR, KRAM F-54868; the Arpaşu Mare peak, alpine meadow, N 45³5'48”, E 2440'49”, alt. 2460 m, 12-08-2004, leg. AR, MR, KRAM F-54869; Iezer-Păpuşa Massif, E crest of the Iezeru Mare peak, alpine meadow, N 4528'01'”, E 245ㄱ'14, alt. 2400 m, 31-07-2004, leg. AR, MR, KRAM F-54870, alt. 2450 m, 31-07-2004, leg. AR, MR, KRAM F-54872; vicinity of lake Lacul Iezeru, alpine meadow, N 45'27'38”, E 2457'40”, alt. 2140 m, 30-07-2004, leg. AR, MR, KRAM F-54871; Munții Latoriței, the Vf. Fratoşteanu Mare peak, alpine meadow, N 4524'14", E 2348'17', alt. 2503 m, 16-08-2004, leg. AR, MR, KRAM F-54876; Munții Lotru, the Vf. Cristeşti peak, alpine meadow, N 45³1'37', E 2347'24', alt. 2180 m, leg. AR, MR, KRAM F-54873; the Vf. Ştefleşti peak, edge of the postglacial kettle, alpine meadow, N 4531'55', E 2348'27’, alt. 2220 m, 13-08-2004, leg. AR, MR, KRAM F-54875; Munții Cindrel, the Vf. Cindrelu Mare peak, Căldarea Iezeru Mic, alpine meadow, N 4534'43”, E $23^{\circ} 48^{\prime} 07^{\prime \prime}$, alt. $2200 \mathrm{~m}, 14-08-2004$, leg. AR, MR, KRAM F-54874.

Lichenomphalia umbellifera (L.: Fr.) Redhead, Lutzoni, Moncalvo \& Vilgalys

Notes on distribution. Lichenomphalia umbellifera is common in lowland as well as arctic and alpine habitats. It is also frequent in the Western Carpathians (e.g. Adamčik 1998b, Olech 2004). 
Specimens examined. Munții Făgărașului, upper part of the Valea Podragului valley (towards the Şaua Podragului pass), on a large stone covered with Salix retusa, N 45³6'17', E 2441'18', alt. 2270 m, 05-08-2004, leg. AR, MR, KRAM F-54889; the Ucea Mare peak, alpine meadow, N 45³6'24”, E 2443'16”, alt. 2430 m, 07-08-2004, leg. AR, MR, KRAM

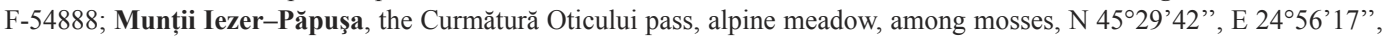
alt. 2350 m, 31-07-2004, leg. AR, MR, KRAM F-54887; Munții Lotru, the Vf. Ştefleşti peak, edge of the postglacial kettle, alpine meadow, N 45³1'55", E 2348'27'”, alt. 2220 m, 13-08-2004, leg. AR, MR, KRAM F-54893; the Vf. Cristeşti peak, alpine meadow, among mosses, N 45³1'37', E 2347'24”, alt. 2180 m, 13-08-2004, leg. AR, MR, KRAM F-54892; Munții Cindrel, the Vf. Cindrelu Mare peak, Căldarea Iezeru Mic, alpine meadow, among mosses (Sphagnum), N 45³4'43”, E 2348'07”, alt. 2200 m, 14-08-2004, leg. AR, MR, KRAM F-54891; Munții Latoriței, the Vf. Fratoşteanu Mare peak, alpine meadow, among mosses, N 45²4'14”, E 2348'17’, alt. 2053 m, leg. AR, MR, KRAM F-54890.

\section{Mycena citrinomarginata Gillet}

Observations. The collected specimens are characterized by yellow brownish, greyish yellow colours (4B6, 4C4-5) of the cap which was darker in the centre and almost white at the margin, by yellow lamella edges and numerous lageniform to fusiform cheilocystidia which are simple or with a few short or long, apical or lateral, simple or branched excrescences.

Notes on distribution. Mycena citrinomarginata probably represents the montane-boreal element as it occurs more often in boreal regions and mountainous habitats than in lowlands. It is also frequently recorded in arctic areas and alpine zones. In the Western Carpathians, it has been found in the subalpine zone a number of times. The species is new to Romania.

Specimen examined. Munții Făgăraşului, upper part of the Valea Podragului valley (towards the Şaua Podragului

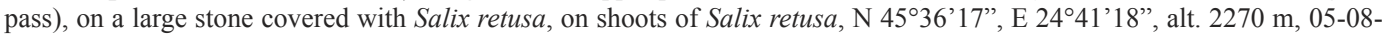
2004, leg. AR, MR, KRAM F-54916.

Mycena leptocephala (Pers.: Fr.) Gillet

Notes on distribution. Mycena leptocephala is a widespread species occurring mainly in lowland sites. In the Western Carpathians, it is more common in subalpine forests.

Specimen examined. Munții Făgăraşului, upper part of the Valea Podragului valley (towards the Şaua Podragului

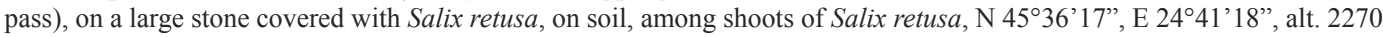
m, 05-08-2004, leg. AR, MR, KRAM F-54917.

\section{Russula heterochroa Kühner}

Fig. 8.

Description. Cap 2-4 cm in diameter, convex with slightly decurved margin, dark vine red, blackish violet, violet purple to lilac violet (10D8, 10E6-8, 10F6-8, 9B5, 9E7-8, 9F3-5, 9F7-8, 8E7, $8 \mathrm{~F} 7,11 \mathrm{~B} 4,11 \mathrm{~F} 5-6,11 \mathrm{E} 8)$, uniformly coloured, or with pale lilac, cream or yellowish brown (5D7, 5E7) centre, surface smooth, greasy, margin smooth or slightly sulcate. Lamellae first white then cream to yellow (3A3, 4A2-6). Stipe $2-3 \times 0.7-1.5 \mathrm{~cm}$, clavate to slightly bulbous, white. Flesh white, under the pileipellis lilac-rose (9A3), about $3 \mathrm{~mm}$ thick in the cap centre, smell none, taste mild. Spore-print cream yellow (III c, "ochre foncé" according to Romagnesi 1967).

Spores broadly ellipsoid to ovoid, 10-12 $\times 8-9 \mu \mathrm{m}$, covered with isolated spines up to $1.5 \mu \mathrm{m}$ high. Basidia 45-50 × 11-13 $\mu \mathrm{m}$, with 2 sterigmata. Pleurocystidia 60-100 $\times 7-13 \mu \mathrm{m}$, fusiform, narrowly fusiform to cylindric. Dermatocystidia present, narrow, 5-6 $\mu \mathrm{m}$ in diameter, 2-4-septate, marginal cells of pileipellis $2.5-4.5 \mu \mathrm{m}$ in diameter, cylindric, single or branched, septate.

Notes on distribution. Russula heterochroa is a very rare alpine species reported by Kühner (1975b) from the French Alps and Swedish Lapland. The records from the Munții Bucegi massif are the first for this species in the Carpathians. The species is new to Romania.

Specimens examined. Munții Bucegi, at the Şaua Şugărilor pass, alpine meadow with Polygonum viviparum and Dryas octopetala, N 4525'54”, E 2527'34”, alt. 2400 m,, 27-07-2004, leg. AR, MR, KRAM F-55101, 55098, 55099; Mun- 


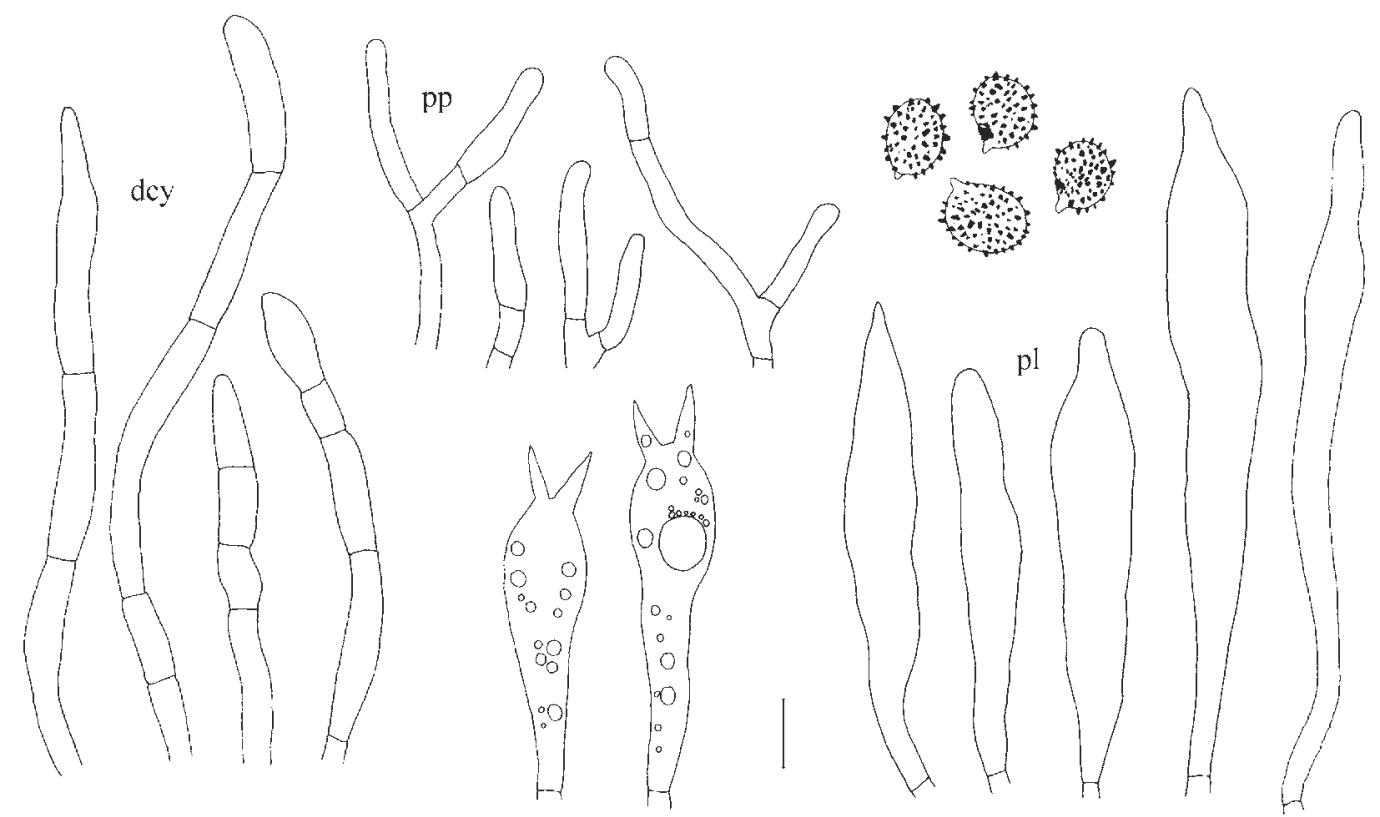

Fig. 8. Russula heterochroa Kühner, coll. KRAM F-55098: dcy - dermatocystidia, pp - elements of pileipellis, $\mathrm{pl}$ - pleurocystidia; scale bar $=10 \mu \mathrm{m}$.

tele Caraiman, calcareous (?) rocks near the marked trail to the Vf. Caraiman peak, alpine meadow with Dryas octopetala, N 4524'51”, E 25²9’34”, alt. 2400 m, 26-07-2004, leg. AR, MR, KRAM F-55100.

\section{Russula nana Killerm.}

Observations. Russula nana was the most frequently encountered species in the alpine zone of the Southern Carpathians. The fungus has no special preferences regarding either the edaphic condition or the mycorrhizal host. It occurred on calcareous and siliceous bedrock, and grew together with Salix spp., Dryas octopetala or Polygonum viviparum. Although recorded only in two massifs so far, it should also be found in other regions.

Notes on distribution. Russula nana is one of the most common arctic-alpine species occurring in arctic areas of Norway, Sweden, Finland, Russia, Canada, Greenland, the Faroe Islands, Scotland, Alaska, Svalbard, Iceland, in the alpine zone of the Norwegian mountains, the Polar Urals, the Swiss, French, Austrian, Italian and German Alps and the Pyrenees (Favre 1955, Horak 1960, Lange \& Skifte 1967, Gulden \& Lange 1971, Kühner 1975b, Watling 1977, Knudsen \& Borgen 1982, Lamoure 1982, Lamoure et al. 1982, Linkins \& Antibus 1982, Miller 1982, Watling 1983, Bon 1985a, Gulden et al. 1985, Irlet 1985, Schmid-Heckel 1985, Kühner \& Lamoure 1986, Bon 1987b, Bon \& Cheype 1987, Senn-Irlet 1987, Watling 1987, Senn-Irlet 1988, Bon 1991, Hansen \& Knudsen 1992, Ohenoja \& Ohenoja 1993, Senn-Irlet 1993, Bon \& Ballarà 1996, Knudsen \& Mukhin 1998, Peintner 1998, Sarnari 1998, Vesterholt 1998, Bresinsky et al. 2000, Niezdoiminogo 2003, G. Gulden, pers. comm.). The fungus is also very common in the alpine zone of the Western Carpathians (Nespiak 1960, Tondl 1988, Fellner \& Landa 1991, 1993, Adamčik 1998a). The species is new to Romania.

Specimens examined. Munții Bucegi, at the Cabana Babele hostel, alpine meadow with Polygonum viviparum, N 4524'22”, E 2528'21", alt. 2200 m, 25-07-2004, leg. AR, MR, KRAM F-54926; the same locality, 27-07-2004, leg. EC, JC, 
KRAM F-54927; at the Şaua Şugărilor pass, alpine meadow with Polygonum viviparum and Dryas octopetala, N 45²5'54', E 25²7'34", alt. 2400 m, 27-07-2004, leg. AR, MR, KRAM F-54928; between Vf. Caraiman and Vf. Coştila peaks, alpine meadow with Polygonum viviparum, N 45²5'01', E 25²9'06”, alt. 2385 m, 26-07-2004, leg. JC, KRAM F-54929; main plateau, slopes between the Cabana Babele hostel and Muntele Caraiman, alpine meadow with Polygonum viviparum, N 4524'39", E 2528'25", alt. 2200 m, 26-07-2004, leg. AR, MR, KRAM F-54930; S from the Vf. Omul peak, alpine meadow with Polygonum viviparum, N 45²5’54”, E 25²7’34”, alt. 2500 m, 27-07-2004, leg. AR, MR, KRAM F-54931; Munții Făgăraşului, S-W slopes of the Arpaşu Mic peak, alpine meadow with Dryas octopetala and Salix retusa, N 4535'41', E 24³9'19”, alt. 2250 m, 03-08-2004, leg. AR, MR, KRAM F-54932; the Țarâta peak, alpine meadow with Dryas octopetala, Polygonum viviparum, Salix reticulata, and Salix retusa, N 45³6'20”, E 2441'42”, alt. 2440 m, 05-08-2004, leg. AR, MR, KRAM F-54933; E ridge of the Ucişoara peak, alpine meadow with Polygonum viviparum, Salix reticulata, and Salix retusa, N 4536'27', E 2443'49”, alt. 2400 m, 05-08-2004, leg. AR, MR, KRAM F-54934; N slopes of the Şaua Podragului pass, alpine meadow with Polygonum viviparum and Salix reticulata, N 45³6'15', E 2441'23”, alt. 2330 m, 07-08-2004, leg. AR, MR, KRAM F-54935; the Arpaşu Mare peak, alpine meadow with Dryas octopetala, N 45³5'48', E 2440'49”, alt. 2460 m, 08-08-2004, leg. AR, MR, KRAM F-54936.

\section{Russula saliceticola (Singer) Kühner ex Knudsen \& T.Borgen}

Notes on distribution. Russula saliceticola is known from alpine and arctic-subarctic habitats in Norway, Sweden, Finland, Greenland, Iceland, the Faroe Islands, Swedish and Norwegian mountains, the Swiss, French and German Alps (Favre 1955, Kühner 1975b, Knudsen \& Borgen 1982, Lamoure et al. 1982, Schmid-Heckel 1985, Bon 1991, Hansen \& Knudsen 1992, Vesterholt 1998, G. Gulden, pers. comm.). Russula saliceticola is also present in the Western Carpathians (Fellner \& Landa 1993, Knudsen \& Ronikier 2003). The species is new to Romania.

Specimens examined. Munții Făgăraşului, N slopes of the Şaua Podragului pass, alpine meadow with Polygonum viviparum and Salix reticulata, N 45³6'15”, E 2441'23”, alt. 2330 m, 07-08-2004, leg. AR, MR, KRAM F-54937; the Țarâta peak, alpine meadow with Dryas octopetala, Polygonum viviparum, Salix reticulata, and Salix retusa, N $45^{\circ} 36^{\prime} 20^{\prime \prime}$, E 2441'42", alt. 2440 m, 05-08-2004, leg. AR, MR, KRAM F-54939; the Portița Arpaşului pass, alpine meadow with Polygonum viviparum, N 45³6'00”, E 2439'23”, alt. 2170 m, 08-08-2004, leg. AR, MR, KRAM F-54940; the Arpaşu Mare peak, alpine meadow, N 45³5'48', E 2440'49”, alt. 2460 m, 12-08-2004, leg. AR, MR, KRAM F-54941; Munții Latoriței, N slopes of the Vf. Fratoşteanu Mare peak, alpine meadow, among mosses, N 45²4'38”, E 2347'57', alt. 1980 m, 16-08-2004, leg. AR, MR, KRAM F-54938.

\section{ACKNOWLEDGEMENTS}

I am greatly indebted to Michał Ronikier for his help in collecting, describing and photographing fungi in the field. Special thanks are also due to Catalin Tănase (Iaşi, Romania) for his help in gathering Romanian literature, to Pierre-Arthur Moreau (Lille, France) for his remarks on Inocybe microfastigiata and assistance with literature, and to a reviewer for the insightful comments on the manuscript. This study was partly carried out within the framework of the project financed by the Polish Ministry of Education and Science, grant no. 2P04C 086 30. Field collection of fungi was financially supported by grants from EU project INTRABIODIV (6th FP). The author's attendance at the ISAM7 was supported by the Foundation for the Polish Science and Foundation for Polish Botany.

\section{REFERENCES}

Adamčik, S. 1998a. Dva typické alpínske druhy - pavučinovec drobný Cortinarius pauperculus a plávka vysokohorská Russula nana. - Spravodajca slovenských Mykológov 6: 11-14. 
Adamčik, S. 1998b. Kalichovky na rašeliniskách. - Spravodajca slovenských Mykológov 6: 32-36. Antonín, V. \& Škubla, P. 2000. Interesting macromycetes found in the Czech and Slovak Republics. - Fungi non delineati 11: 1-46.

Bas, C. 1977. Species-concept in Amanita sect. Vaginatae. - In: Clémençon, H. (ed.), The species concept in Hymenomycetes, Cramer, Vaduz, pp. 79-91.

Basso, M.T. 1999. Fungi Europaei. Vol. 7: Lactarius Pers. - Mykoflora, Alassio.

Bigelow, H.E. 1970. Omphalina in North America. - Mycologia 57: 1-32.

Bizio, E. 1995. Alcune Inocybe più frequenti della zona alpina delle Dolomiti. - Rivista Micol. 2: Suppl.: 3-60.

Bizio, E. 1997. Alcune Inocybe più frequenti della zona alpina delle Dolomiti $2^{\circ}$ contributo. - Rivista Micol. 4: 339-362.

Boertmann, D. 2000. Fungi of Northern Europe. Vol 1: The genus Hygrocybe. - Svampetryk, Greve.

Bon, M. 1985a. Stage Mycologie Alpine Lanslebourg (Savoie) du 1 au 3 septembre 1984. - Bull. trimestr. Féd. Mycol. Dauphiné-Savoie 96: 19-25.

Bon, M. 1985b. Quelques noveaux taxons de la flore mycologique alpine. - Bull. trimestr. Féd. Mycol. Dauphiné-Savoie 97: 23-30.

Bon, M. 1987a. Amanita oreina (Favre) Heim ex Bon comb. nov. - Bull. trimestr. Féd. Mycol. Dauphiné-Savoie 105: 17-20.

Bon, M. 1987b. Quelques recoltes mycologiques de la zone alpine au 7ème Convegno di Micologia - Fiera di Primiero (Italie). - Micol. ital. 3: 267-270.

Bon, M. 1990. Mycologie alpine 24/27 Août 1989 - "Les Menuires". - Bull. trimestr. Féd. Mycol. Dauphiné-Savoie 116: 25-30.

Bon, M. 1991. Inventaires des espèces récoltées au stage mycologie alpine (Les Arcs - 23-26 Août 1990). - Bull. trimestr. Féd. Mycol. Dauphiné-Savoie 122: 25-28.

Bon, M. 1992. Quelques Inocybes alpins au stage de mycologie des Arcs du 30 Août au 1 Septembre 1991. - Bull. trimestr. Féd. Mycol. Dauphiné-Savoie 126: 19-22.

Bon, M. 1996. Inocybe nespiakii comb. nov. - Doc. mycol. 26 (102): 20.

Bon, M. 1997. Clé monographique des Inocybes alpines. - Bull. trimestr. Féd. Mycol. DauphinéSavoie 144: 71-109.

Bon, M. \& Ballarà, J. 1996. Aportació a l'estudi de la micoflora alpina dels Pirineus (2a part). - Revista Catalana Micol. 19: 139-153.

Bon, M. \& Cheype, J.-L. 1987. Mycologie alpine au col du Joly Haute-Savoie; altitude 2000 m. - Bull. trimestr. Féd. Mycol. Dauphiné-Savoie 106: 22-27.

Bontea, V. 1985. Ciuperci parasite şi saprofite din România. Vol. 1. - Editura Academiei Republici Socialiste România, Bucureşti.

Borgen, T. \& Arnolds, E. 2004. Taxonomy, ecology and distribution of Hygrocybe (Fr.) P.Kumm. and Camarophyllopsis Herink (Fungi, Basidiomycota, Hygrocybeae) in Greenland. - Meddr Grønland Biosci. 54: 1-68.

Bresinsky, A., Kreisel, H., Beisenherz, M. \& Eger, A. 2000. Mycologishes aus dem Werdenfelser Land: Bovista bovistoides, Lactarius salicis-reticulatae neu für Deutschland und weitere Pilze. - Z. Mykol. 66: 123-150.

Bresinsky, A. \& Schmid-Heckel, H. 1982. Der Lärchenporling und verschiedene Blätterpilze aus den Berchtesgadener Alpen neu für die Bundesrepublik nebst einer Liste indigener Lärchenbegleiter - Ber. bayer. bot. Ges. 53: 47-60.

Bresinsky, A. \& Schmid-Heckel, H. 1983. Agaricales aus der alpinen Zone Bayerns. - Ber. bayer. bot. Ges. 54: 141-150.

Bujakiewicz, A. 1993. Fungi of the alpine and subalpine zones of the Babia Góra massif. - In: Pegler, 
D.N., Boddy, L., Ing, B. \& Kirk, P.M. (eds), Fungi of Europe: Investigation, Recording and Conservation. Royal Botanic Gardens, Kew, pp. 115-120.

Campo, E. \& Bizio, E. 2000. Le Amanita della zona alpina in Italia: troppi nomi per una sola specie. - Boll. Gruppo micol. G. Bresadola N.S. 43: 175-187.

Elborne, S.A. \& Knudsen, H. 1990. Larger fungi associated with Betula pubescens in Greenland. - Meddr Grønland Biosci. 33: 77-80.

Eliade, E. 1961. Contribuții la cunoaşterea macromicetelor din masivul Bucegi şi imprejurimi. - Anal. Univ. C. I. Parhon. Biol. 28: 49-63.

Eliade, E. 1963. Cîteva aspecte din flora micologică a Munților Bucegi. - Ocrotirea narurii 7: 119128.

Eliade, E. 1964. Cîteva macromicete noi şi rare din regiunea Sinaia. - Natura Ser. biol. 6: 71-73.

Eliade, E. \& Toma, M. 1977. Contribuții la cunoaşterea macromicetelor din masivul Bucegi. - Anal. Univ. Bucureşti. Biol. 26: 57-61.

Esteve-Raventós, F. \& Vila, J. 1998. Algunos Inocybe de la zona alpina de los Pirineos de Catalunya. II. - Revista Catalana micol. 21: 185-201.

Favre, J. 1955. Les champignons supérieurs de la zone alpine du Parc National Suisse. - Ergebn. wiss. Untersuch. schweiz. NatParkes 5: 1-212.

Fellner, R. \& Landa, J. 1991. Arctic and alpine fungi in Czechoslovakia. - Czech Mycol. 45: 35.

Fellner, R. \& Landa, J. 1993. Some species of Cortinariaceae and Russulaceae in the alpine belt of the Belaer Tatras - II. - Czech Mycol. 47: 45-55.

Flakus, A. \& Bielczyk, U. 2006. New and interesting records of lichens from Tatra Mts. - In: Lackovičová, A., Guttová, A., Lisická, E. \& Lizoň, P. (eds), Central European lichens - diversity and threat. Mycotaxon, Ithaca. pp. 239-250.

Gerhold, N. 1986. Zwei Nordtiroler Funde zum 'Zwergstrauch-Scheidenstreifling' Amanita nivalis R. K. Greville 1822. - Beitr. Kenntn. Pilze Mitteleur. 2: 15-17.

Gulden, G., Jenssen, K.M. \& Stordal, J. 1985. Arctic and Alpine Fungi - 1. - Soppkonsulenten, Oslo.

Gulden, G. \& Lange, M. 1971. Studies in Macromycetes Flora of Jotunheimen, the Central Mountain Massif of Norway. - Norw. J. Bot. 18: 1-46.

Hansen, L. \& Knudsen, H. 1992. Nordic Macromycetes. Vol. 2. - Nordsvamp, Copenhagen.

Heim, R. 1931. Encyclopedie Mycologique, Vol. 1: Le genre Inocybe. - Lechevalier, Paris.

Horak, E. 1960. Die Pilze im Gletschervorfeld (2290-2350 m) des Rotmoos ferners in den Ötztaler Alpen. - Nova Hedwigia 2: 487-508.

Horak, E. 1987. Astrosporina in the alpine zone of the Swiss National Park (SNP) and adjacent regions. - In: Laursen, A., Ammirati, J.F. \& Redhead, S.A. (eds), Arctic and alpine mycology II. Plenum Publ., New York, pp. 205-234.

Horak, E. 1993. Entoloma in the alpine zone of the Alps: 1. Revision of the taxa described by J. Favre (1955). 2. New records from the Swiss National Park and other locations in the Alps. - In: Petrini, O. \& Laursen, G.A. (eds), Arctic and alpine mycology III-IV. Cramer, Berlin, pp. 63-91.

Irlet, B. 1985. Cadmium und Blei in Pilzen aus der alpinen Stufe der schweizer Alpen. - Mycol. helv. 1: 393-399.

Jamoni, G. 1998-99. Gli igrofori della zona alpina del Monte Rosa Vercellese. - Fung. Ambiente 78-79: 27-88.

Jamoni, G. \& Bon, M. 1995. Note di micologia alpina reperti rari e nuovi della zona alpina del massiccio del Monte Rosa (4e parte). - Rivista micol. 2: Suppl: 61-74.

Knudsen, H. \& Borgen, T. 1982. Russulaceae in Greenland. - In: Laursen, G.A. \& Ammirati, J.F. (eds), Arctic and alpine mycology I. Univ. of Washington, Seattle, pp. 216-238. 
Knudsen, H. \& Borgen, T. 1987. Agaricaceae, Amanitaceae, Boletaceae, Gomphidiaceae, Paxillaceae and Pluteaceae in Greenland. - In: Laursen, A., Ammirati, J.F. \& Redhead, S.A. (eds), Arctic and alpine mycology II. Plenum Publ., New York, pp. 235-253.

Knudsen, H. \& Mukhin, V.A. 1998. The arctic-alpine agaric element in the Polar Ural and Yamal, Western Siberia. - In: Mukhin, V.A. \& Knudsen, H. (eds), Arctic and alpine mycology V, Yekaterinburg Publ., Yekaterinburg, pp. 152-162.

Knudsen, H. \& Ronikier, A. 2003. Agarics from the alpine zone of the Tatra mountains. - Abstr., XIV Congr. Eur. Mycol., Katsiveli, Yalta, Crimea, Ukraine, 22-27 Sept. 2003, pp. 97-98.

Kornerup, A. \& Wanscher, J.H. 1965. Farver i farver [Methuen handbook of colour]. - Politiken, København.

Kotlaba, F. 1959. Př́spěvek k mykofloře Rumunska. - Česká Mykol. 13: 140-152.

Kühner, R. 1972. Agaricales de la zone alpine. Amanitacées. - Ann. sci. Univ. Besançon Bot. 3: 31-38.

Kühner, R. 1975a. Agaricales de la zone alpine. Genre Lactarius D.C. ex S.F. Gray. - Bull. Soc. mycol. France 91: 5-69.

Kühner, R. 1975b. Agaricales de la zone alpine. Genre Russula Pers. ex S. F. Gray. - Bull. Soc. mycol. France 91: 313-390.

Kühner, R. 1977. Agaricales de la zone alpine. Genre Hygrocybe (Fries) Kummer. (suite et fin). - Bull. Soc. mycol. France 93: 53-115.

Kühner, R. 1988. Diagnoses de quelques nouveaux Inocybe récoltés en la zone alpine de la Vanoise. - Docums mycol. 19: 1-27.

Kühner, R. \& Lamoure, D. 1986. Catalogue des Agaricales (Basidiomycètes) de la zone alpine du Parc National de la Vanoise et des régions limitrophes. - Trav. sci. Parc nat. Vanoise 15: 103-187.

Lamoure, D. 1982. Agaricales de la zone alpine du Parc National des Écrins. Première contribution: Haute Valée de la Romanche. - Trav. sci. Parc nat. Écrins 2: 119-123.

Lamoure, D. 1993. Nuclear behavior in some omphaloid fructifications of the Basidiolichens Botrydina and Coriscium. - In: Petrini, O. \& Laursen, G.A. (eds), Arctic and alpine mycology III-IV. Cramer, Berlin, pp. 155-160.

Lamoure, D., Lange, M. \& Petersen, P.M. 1982. Agaricales found in the Godhavn area, W Greenland. Nord. J. Bot. 2: 85-90.

Lange, M. 1955. Macromycetes. Part II. Greenland Agaricales (Pleurotaceae, Hygrophoraceae, Tricholomataceae, Amanitaceae, Agaricaceae, Coprinaceae and Strophariaceae). - Meddr Grønland Biosci. 147: 11: 1-69.

Lange, M. \& Skifte, O. 1967. Notes on the macromycetes of Northern Norway. - Acta borealia A scient. 23: 1-51.

Linkins, A.E. \& Antibus, R.K. 1982. Mycorrhizae of Salix rotundifolia in coastal arctic tundra. - In: Laursen, G.A. \& Ammirati, J.F. (eds), Arctic and alpine mycology I, Univ. Washington, Seattle, pp. 509-525.

Lisicka, E. 1999. Poznámka k rozšíreniu kalichoviek na rašeliniskách. - Spravodajca slovenských Mykológov 7: 23-25.

Miller, O.K., Jr. 1968. Interesting fungi of the St. Elias mountains, Yukon Territory, and adjacent Alaska. - Mycologia 60: 1190-1203.

Miller, O.K., Jr. 1982. Higher fungi in Alaskan subarctic tundra and taiga plant communities. - In: Laursen, G.A. \& Ammirati, J.F. (eds.), Arctic and alpine mycology I, Univ. of Washington, Seattle, pp. 123-143.

Moruzi, C., Petria, E., \& Mantu, E. 1967. Catalogul lichenilor din România. - Acta Botanica Horti Bucurestiensis, Bucureşti 1967: 1-389.

Moser, M. \& McNight, K. H. 1987. Fungi (Agaricales, Russulales) from the alpine zone of Yellow- 
stone National Park and the Beartooth mountains with special emphasis on Cortinarius. - In: Laursen, A., Ammirati, J.F. \& Redhead, S.A. (eds), Arctic and alpine mycology II. Plenum Publ. New York, pp. 299-317.

Nespiak, A. 1960. Notatki mikologiczne z Tatr. - Fragm. Florist. Geobot. 6: 709-724.

Nespiak, A. 1990. Grzyby (Mycota), Vol. 19: Strzępiak (Inocybe). - Państwowe Wydawnictwo Naukowe, Warszawa.

Niezdoiminogo, E.L. 2003. Biogeographical reviev of agaricoid fungi from Russian arctic. - Mikol. Fitopatol. 37: 28-35.

Ohenoja, E. \& Ohenoja, M. 1993. Lactarii of the Franklin and Keewatin Districts of the Northwest Territories, Arctic Canada. - In: Petrini, O. \& Laursen, G.A. (eds.), Arctic and alpine mycology III-IV. Cramer, Berlin, pp. 179-192.

Olech, M. 2004. Lichens of the Tatra National Park. - W. Szafer Institute of Botany, Polish Academy of Sciences, Kraków.

Peintner, U. 1998. Lead and cadmium contents of Basidiomycetes along a heavily trafficated high mountain pass road in the Austrian Alps. - In: Mukhin, V.A. \& Knudsen, H. (eds), Arctic and alpine mycology V. Yekaterinburg Publ., Yekaterinburg, pp. 122-127.

Pop, A. 1989. Helotiales (Ascomycetes) from the Scientific reserve of the Retezat National Park. - Rev. roumaine Biol. 34: 31-36.

Redhead, S.A. \& Kyuper, T.W. 1987. Lichenized agarics: taxonomic and nomenclatural riddles. - In: Laursen, A., Ammirati, J.F. \& Redhead, S.A. (eds), Arctic and alpine mycology II. Plenum Publ., New York, pp. 319-349.

Romagnesi, H. 1967. Les Russules d'Europe et d'Afrique du Nord. - Bordas.

Ronikier, M. 1996a. Karpaty Rumuńskie. - Pamiętnik Polskiego Towarzystwa Tatrzańskiego 5: 31-32.

Ronikier, M. 1996b. Karpaty Południowe, szkic topograficzno-turystyczny. - Pamiętnik Polskiego Towarzystwa Tatrzańskiego 5: 61-92.

Sarnari, M. 1998. Monografia illustrata del Genre Russula in Europa, Vol. 1. - A. M. B. Fondazione Centro Studi Micologici, Brescia.

Schmid-Heckel, H. 1985. Zur Kenntnis der Pilze in der Nördlishen Kalkalpen. - NatPark Berchtesgaden ForschBer. 8: 1-201.

Senn-Irlet, B. 1987. Pilze aus der alpinen stufe des Val d'Anniviers (Wallis). - Bull. murith. Soc. Valais Sci. nat. 105: 87-105.

Senn-Irlet, B. 1988. Macromycetes in alpine snow-bed communities - mycocoenological investigations. Acta bot. neerl. 37: 251-263.

Senn-Irlet, B. 1993. The mycoflora of alpine mire communities rich in Salix. - In: Petrini, O. \& Laursen, G.A. (eds.), Arctic and alpine mycology III-IV. Cramer, Berlin, pp. 235-249.

Skirgiełło, A. 1998. Grzyby (Mycota), Vol. 25: Mleczaj (Lactarius). - Instytut Botaniki im. W. Szafera, PAN, Kraków.

Škubla, P. 1999. Vzácne macromycéty alpínskej mykoflóry Belianskych Tatier. - Spravodajca slovenských mykológov 7: 10-13.

Soran, V., Biro, J., Moldovan, O. \& Ardelean, A. 2000. Conservation of biodiversity in Romania. - Biodiv. Conserv. 9: 1187-1198.

Stangl, J. 1989. Die Gattung Inocybe in Bayern. - Hoppea 46: 1-409.

Toma, M. \& Diaconescu, F. 1971. Macromicete din masivul Leaota. - Anal. Ştiințifice Univ. “Al. I. Cuza" Iaşi Biol. 17: 373-377.

Tondl, F. 1988. Russula nana v západních Tatrách. - Mykol. Listy 32: 4-8.

Tondl, F. 1989a. Amanita nivalis Greville v Záp. Tatrách. - Mykol. Listy 36: 10-12.

Tondl, F. 1989b. Omphalina hudsoniana anebo Phytoconis viridis? - Mykol. Listy 37: 13-15. 
Trimbach, J. 1983. Materiel pour une "check-list" des Alpes Maritimes (suite). - Docums mycol. 13: 43-54.

Vesterholt, J. 1998. A check-list of fungi recorded from the Faroe Islands. - Fróðskaparrit 46: 3365.

Vila, J., Llistosella, J. \& Llimona, X. 1998. Contributió al. coneixement dels fongs de l'estatge alpí dels Pirineus de Catalunya. II. - Revista Catalana Micol. 21: 93-113.

Vila, J., Esteve-Raventós, F., Llistosella, J. \& Llimona, X. 2001. Contributió al conocimiento de los hongos del piso alpino de los Pirineos de Cataluña. III. - Revista Catalana Micol. 23: 51-65.

Watling, R. 1977. Larger fungi from Greenland. - Astarte 10: 61-71.

Watling, R. 1983. Larger cold-climate fungi. - Sydowia 36: 308-325.

Watling, R. 1987. Larger arctic-alpine fungi in Scotland. - In: Laursen, A., Ammirati, J.F. \& Redhead, S.A. (eds), Arctic and alpine mycology II. Plenum Publ., New York, pp. 17-45. 